(iD) https://orcid.org/0000-0003-1432-8368 Instytut Badań Literackich PAN

maria.prussak@ibl.waw.pl

\title{
NIESTABILNY TEKST PANA TADEUSZA
}

\section{Abstract}

\section{The Unstable Text of Pan Tadeusz}

The article discusses the changes introduced by the successive editors of Adam Mickiewicz's narrative poem to the text version published by the poet himself. The most important one is undoubtedly the addition of the poem considered the "epilogue" to Pan Tadeusz, allegedly lost by Mickiewicz. No less radical are the interventions consisting in supplementing the text with fragments from the autograph or with the poet's later additions made to the already printed text, as well as in corrective conjectures in instances regarded by the publisher as slips of the pen. The article compares the surviving authorial versions of the text, demonstrating that Mickiewicz himself treated his work as a continual process and tested new solutions on various occasions; however, there is no evidence that he intended to introduce them into the printed text.

Keywords: autograph, conjecture, text modernisation, authorial intention, text dynamics

Slowa kluczowe: autograf, koniektura, modernizacja, intencja autora, dynamika tekstu

Dziś już bez trudu na stronach bibliotek cyfrowych można przeczytać oba autorskie wydania Pana Tadeusza (Paryż 1834 i Paryż 1844). Wnikliwy obserwator z pewnością zauważy, jak bardzo różnią się od tekstu poematu, który dają nam do ręki współcześni edytorzy. Jeśli nawet za reprezentantami tradycyjnych koncepcji edytorskich uznać, że modernizacja ortografii i interpunkcji jest sprawą oczywistą, co kwestionuje coraz więcej osób zajmujących się problemami tekstu, to i tak odstępstw od pierwodruku jest zadziwiająco wiele. Nie zamierzam teraz zagłębiać się w różnice grafii, 
warto jednak zwrócić uwagę na zjawisko, o którym pisała Teresa Winek w książce o historii edycji Pana Tadeusza, komentując paryskie wydanie Juliana Klaczki i Eustachego Januszkiewicza z 1860 roku:

Niektóre zmiany „gubiły” dosyć dużo z języka poety, np. „Pan” pisane w pierwodruku wielką literą przy nazwach stanowisk i tytułów szlacheckich, w P 1860 drukowane małą literą, zatracało dostojeństwo nazwy, bardziej natomiast oddawało ówczesny stosunek do zjawiska zwanego tytułomanią szlachecką (Winek 2011: 91).

Już pięć lat po śmierci poety wydawcy zaczęli dostosowywać językowe wyczucie autora do własnych przyzwyczajeń.

Edytorzy, którzy opracowywali tekst już bez udziału Mickiewicza, uważali za swój obowiązek przybliżenie utworu kolejnym pokoleniom czytelników, a także wprowadzanie korekt i uzupełnień uznawanych za oczywiste, najczęściej na podstawie jedynie intuicji. W rezultacie oddalali się od pierwodruku coraz bardziej. W wydaniach autorskich nie ma wiersza dziś znanego jako [Epilog] „Pana Tadeusza”. Znalazł się tam właśnie w roku 1860, wydrukowany na początku tekstu jako prolog. Kiedy w papierach Mickiewicza Klaczko i Januszkiewicz trafili na brulion wiersza zaczynającego się najpierw od incipitu „O czym-że dumać na paryskim bruku”, poprawionego przez poetę na wersję „O tym-że dumać...”, uznali, że jest to fragment poematu. Najprawdopodobniej wspomnienie kraju lat dziecinnych wydało się im oczywistym nawiązaniem do Pana Tadeusza i wystarczającym powodem, żeby połączyć te dwa teksty. Sądzili jednak, że lepsza jest formuła przekreślona przez Mickiewicza, dlatego stwierdzili, że powinien to być prolog. Wzmianka o czytaniu „powieści o Wiesławie” posłużyła później jako jeszcze jedno uzasadnienie powiązania wiersza z poematem. Pod koniec wieku pojawił się stosowny argument. Brulion ten skojarzono ze zdaniem z listu do Antoniego Edwarda Odyńca pisanego do Drezna. Adresat zdanie o Kazimierzu Brodzińskim włączył do innego listu, datowanego 28 Septembra 1835 roku i opublikowanego w „Kronice Rodzinnej” z dnia 19 czerwca/1 lipca 1870: „Jeśli Brodziński jest jeszcze u was, kłaniaj mu ode mnie. Chociaż nie znam go osobiście, wiesz, jak go wysoko szanuję. Na końcu Tadeusza był do niego ustęp, ale nagłe drukowanie i moje ówczesne zatrudnienia małżeńskie zrobiły, że nie miałem czasu poprawić i umieścić ów epilog. Zostawiłem to do przyszłego (jeśli będzie) wydania" (Mickiewicz 1870: 293). Współcześni wydawcy publikują ten fragment w liście datowanym po 21 lipca 1835 i w zdaniu przedostatnim 
słowo Epilog zapisują kursywą wielką literą (Mickiewicz 2003: 296). Leopold Méyet, który miał w ręku autograf i jako pierwszy oddzielił cytowany fragment od listu z 29 września, też zapisał Epilog wielką literą (Méyet 1906: 5). Rękopis listu się nie zachował, nie wiemy, jak poeta potraktował to słowo, ale współczesna modernizacja ortografii, wprowadzając kursywę i wielką literę, usankcjonowała nieautorski tytuł brulionowego fragmentu. Ustaliło się więc przekonanie, że wiersz trzeba drukować na końcu i tak właśnie go tytułować - „Epilog”. Nieweryfikowane fakty filologiczne stają się podstawą kolejnych niepodważalnych twierdzeń i decyzji wydawców i komentatorów i w ten sposób uzasadniają same siebie.

Dwa oddzielne znaleziska, zestawione arbitralnie, stworzyły tekst, który zaczął żyć własnym życiem, opisanym szczegółowo przez Teresę Winek. Omawiając pierwodruk wiersza, stwierdziła ona kategorycznie: ,prologowa lokalizacja w sposób obligatoryjny złączyła go w organiczną całość z poematem" (Winek 2011: 272), choć i obligatoryjność, i organiczność tamtej decyzji łatwo zakwestionować. Ponieważ wiersz jest brulionem, a kilka zwrotek zostało dopisanych na marginesie, każdy wydawca decyduje, jaki ostateczny kształt trzeba mu nadać i gdzie włączyć marginalia. Podsumowaniem edytorskiej pewności dotyczącej ustalania wątpliwych faktów i niemożliwych do potwierdzenia zamiarów autora jest komentarz Zbigniewa Jerzego Nowaka wydrukowany w ostatniej popularnonaukowej edycji poematu, w tak zwanym wydaniu rocznicowym: „Wiersz ten powstał na wiosnę 1834 r. Mickiewicz nazwał go Epilogiem (w liście do Antoniego Edwarda Odyńca z dn. 21 VII 1835 r.) i zamierzał dołączyć do Pana Tadeusza. Ale nigdy swego wiersza nie wykończył i nie ogłosił" (Mickiewicz 1995: 418). Edytor posłużył się w tym zdaniu arbitralnym podmiotem „Wiersz ten” i niepodlegającą wątpliwości nazwą gatunkową, choć nie ma żadnego dowodu, że w cytowanym liście to o nim mowa, i coraz częściej badacze Mickiewicza dostrzegają jego związek z poetyką późnych wierszy, bliższy niż z Panem Tadeuszem (zob. np. Stefanowska 2001: 335-350).

Problem drugi, nie mniejszy, polega na tym, że w pośmiertnych wydaniach utworu Mickiewicza znalazło się wiele słów, a czasem całych wersów, innych niż w drukach autorskich. Tekstologia Pana Tadeusza, na którą składa się cała biblioteka obszernych rozpraw, zakonserwowała Mickiewiczowski poemat w anachronicznym już dziś myśleniu, że wszystkie autoryzowane publikacje dzieła są skażone rozmaitymi błędami, a zadaniem edytora jest ich korygowanie w zgodzie $\mathrm{z}$ domniemaną intencją autora, która niezmienna istnieje gdzieś $\mathrm{w}$ abstrakcyjnym świecie poza dokumentem, jaki trzymamy 
w ręku. Rekonstruowanie intencji polega zwykle na syntetyzowaniu śladów rozmaitych decyzji autorskich zapisywanych w różnych dokumentach w ciągu nawet kilkunastu lat. W tej szkole edytorstwa naukowego ambicją każdego wydawcy opracowującego tekst jest wytropienie i poprawienie w druku błędów, których wcześniej nikt nie zauważył, ale także dyskusja z ustaleniami poprzedników i odrzucenie ich niesłusznych wyborów. Zmiany wprowadzane do Pana Tadeusza, poczynając od warszawskiej edycji z 1858 roku, pojawiają się, znikają i znowu wracają. W rezultacie nie można dziś mówić o tym, że istnieje jakiś jeden ostateczny, uzasadniony naukowo tekst dzieła - istnieje poemat opublikowany przez autora, niejednakowe wersje poszczególnych edytorów, dokumenty rękopiśmienne i wypisy z dokumentów zaginionych.

Jak przebiegał proces „naprawiania” tekstu skażonego zdaniem uczonych przez korektora, zecera i autorskie przeoczenia, można by analizować - jeśli komuś wystarczyłoby cierpliwości - zestawiając aparaty edytorskie kolejnych wydań. W wydaniach dziewiętnastowiecznych zazwyczaj ich nie ma, trzeba by więc kolacjonować kolejne edycje. Poza tym mało kto spośród czytelników Mickiewicza na tę niestabilność zwraca uwagę, czytamy i interpretujemy tę wersję, którą właśnie mamy pod ręką. Dyskusje edytorów, jak się wydaje, interesują już tylko ich samych. Współcześni czytelnicy mają do czynienia z co najmniej trzema wersjami różniącymi się w szczegółach, czasem dość znaczących. Mogą sięgnąć po tekst opracowany przez Stanisława Pigonia po raz pierwszy w serii Biblioteka Narodowa w 1925 roku, powtórzony po wojnie w wydaniach narodowym i jubileuszowym, po opracowanie Konrada Górskiego w IV tomie Dzieł wszystkich albo Zbigniewa Jerzego Nowaka w wydaniu jubileuszowym. Każde z nich istnieje w wersji naukowej bądź popularnonaukowej oraz w wydaniach popularnych, przeznaczonych dla masowego czytelnika.

W edytorskich dyskusjach wciąż nierozstrzygnięte zostaje pytanie elementarne: jakie argumenty są na tyle przekonujące, żeby decyzje edytorów uznać za niepodważalne? Połączenie zdania z listu do Odyńca z odnalezionym brulionem wiersza takim argumentem z pewnością nie jest. A jednak wciąż jeszcze dzisiaj trudno sobie wyobrazić współczesne wydanie Pana Tadeusza bez tak zwanego epilogu. Autorytet wybitnych mickiewiczologów, tradycja tekstu - przywoływane często w obronie radykalnych emendacji, zwłaszcza takiej jak ta - to argumenty z innego porządku. Należą bardziej do dziejów recepcji niż do autorskiego kształtu poematu. Trzeba je raczej postrzegać jako wyraz intencji edytorów i społecznej historii funkcjonowania dzieła niż jako uzasadnienie dla rekonstruowania hipotetycznej intencji 
autora, bo ta jest dla badaczy dostępna tylko w takim stopniu, w jakim została utrwalona w materialnych dokumentach. Za argumenty niepodważalne, uzasadniające wprowadzanie poprawek można uznać literówki, zniekształcenie składni, zakłócenie rytmu. I w zasadzie nic poza tym. Osiem takich omyłek zauważono w erracie dołączonej do pierwodruku, inne wielokrotnie zostały opisane. Pozostałe emendacje powołują się zwykle na uzasadniające je autorskie źródła i wyjaśnienie edytora, dlaczego zmieniana wersja jest lepsza z punktu widzenia spójności tekstu. I tu pojawia się problem podstawowy - jak tę spójność rozumieć, czy dotyczy ona dokumentu, czy sensu konstruowanego przez badacza na podstawie kilku różnych przekazów.

Edytorzy wprowadzają także poprawki arbitralne tam, gdzie dostrzegają niewątpliwy błąd rzeczowy autora. Tak jest w przypadku zmiany dokonanej w 1868 roku w edycji przygotowanej ,przez dzieci autora”, zmiany przez nikogo później niekwestionowanej, przeciwnie, uzasadnianej na wiele sposobów ${ }^{1}$. Władysław Mickiewicz lub ktoś przez niego upoważniony zmienił w księdze IV w scenie opisującej pogoń Kusego i Sokoła za zającem w wierszu 941 autorski zapis, potwierdzony w druku i w autografie:

Pył za nim, psy za pyłem, zdaleka się zdało,

Że zając, psy i charty jedne tworzą ciało

po zmianie drugi wers brzmi: „Że zając, pył i charty jedne tworzą ciało”, i tak czytamy przez ostatnie 150 lat, nie zwracając uwagi na to, że poprawiony wers stał się fonetycznie mniej udany. Wszyscy kolejni wydawcy tłumaczyli, że Mickiewicz się przepisał i przez nieuwagę powtórzył słowo psy zamiast pył, bo przecież zwrot psy i charty jest nielogiczną tautologią, a w dodatku za zającem biegły tylko charty. Ta emendacja została nawet uznana za modelową w podręcznikach edytorstwa od Konrada Górskiego po Romana Lotha (Górski 2011 [1975]: 21-22; Loth 2006: 76). I tu pojawia się kolejne pytanie: czy edytor ma prawo poprawiać błędy rzeczowe autora nawet wtedy, jeśli są to oczywiste pomyłki. W tym przypadku jednak błędu nie ma. W języku epoki można wskazać inne przykłady użycia zwrotu ,psy i charty”. Tomasz Chachulski przy różnych okazjach zwracał uwagę, że w liście Adama Naruszewicza do nieznanego z imienia Mierzejewskiego znalazła się podobna formuła: „Niech się też stara, abym ja mając takie lasy mógł mieć zimą zwierzynę, a lisy i wilki na kożuch, bo wiem o tym, że on charty i psy dla siebie chowa,

1 Traktowanej jako oczywista do tego stopnia, że nie wspomniała o niej Teresa Winek omawiająca zmiany wprowadzane w kolejnych wydaniach. 
jamy na wilki kopie, lisy bije i sam z tego pożytkuje, a ja nic" (Naruszewicz 1959: 436). Znacznie więcej przykładów poświadczających obecność tego zwrotu w języku przełomu wieków XVIII i XIX przypomniał Marek Piechota, który przywołał również argumenty zabierającego głos w dyskusji Tomasza Chachulskiego. Mimo to swój wywód w obronie zasadności tej edytorskiej emendacji w Panu Tadeuszu, potwierdzonej autorytetem najwybitniejszych znawców mickiewiczowskiej tekstologii, poprzedził podtytułem od razu sugerującym tezę, która powinna zostać udowodniona: „Słynny w mickiewiczologii lapsus calami i jego domniemane klasycystyczne źródło" (Piechota 2014: ). Domniemane jedynie dlatego, że nie przystaje do tezy, czy dlatego, że dla badacza dowody słownikowe mają mniejszą wartość niż siła tradycji tekstu od półtora wieku istniejącego w formie poprawionej przez anonimowego wydawcę i zaakceptowanej przez twórców kolejnych edycji?

Towarzyszących tej emendacji uzupełniających wyjaśnień, że za zającem biegły tylko charty, nie da się udokumentować. W gromadzie wracającej z polowania były i charty, i psy gończe, a zając „,czuł z tyłu myśliwych i psiarnie" (w. 934). Żeby wesprzeć tę decyzję kolejnych wydawców, Stanisław Pigoń w wydaniu Biblioteki Narodowej dodał dość absurdalny przypis do wiersza rozpoczynającego akcję pogoni za szarakiem. Wszystko zaczęło się tak (cytuję wydanie Pigonia):

Tu Wojskiemu przerwał krzyk: „Wyczha!” Tuż spod koni

Smyknął szarak; już Kusy, już Sokół go goni.

Psy wzięto na obławę, wiedząc, że z powrotem

Na polu łatwo można napotkać się z kotem (w. 924-927).

Przypis do w. 926 na siłę próbuje tworzyć dodatkowe uzasadnienie: ,psytutaj oczywiście chodzi o charty; przy obławie były one nieprzydatne" (Mickiewicz 2012: 237). W rezultacie edytor sugeruje czytelnikowi, że autorskie „psy” można czytać rozmaicie. Raz jako charty, następnym razem trzeba je zamienić na ,pył”. Jak widać, edytorskie domniemania i uzasadnienia nie mają granic.

Najczęściej jednak edytorzy zestawiają tekst drukowany z autografem. Istnieje bardzo wiele przykładów pokazujących, jak kolejne wydanie wraca do zapisanej w autografie, wcześniejszej niż druk, wersji jakiegoś fragmentu. Wtedy edytor uzasadnia tę decyzję własną, co dla niego zwykle oznacza lepiej umotywowaną, interpretacją zmienionego wersu. Najczęściej chodzi w tych zmianach o pojedyncze słowo. Na przykład w księdze III w scenie, w której Zosia karmi w ogrodzie wiejskie dzieci, wersy 81 i 82 
w pierwodruku mają postać: „Nie wiedząc, że napastnik już z przeciwnej strony / Zbliżył się, czołgając się jak wąż przez zagony”. Górski wraca tu do formy autografu - „Nie widząc, że napastnik” - i drobiazgowo to uzasadnia: Zosia „skutkiem jednokierunkowego skupienia uwagi nie widzi napastnika zbliżającego się z przeciwnej strony. Akcent położony jest na czynność patrzenia. Przyjmując wersję «nie wiedząc», można by zapytać, skąd miała wiedzieć, jeśli nie oglądała się na wszystkie strony. Błąd Zosi polegał na tym, że mimo obudzonej czujności nie widziała tego, co mogła była zobaczyć" (Górski 1969: XXXII). Ta argumentacja, którą bardzo łatwo zanegować - nie rozglądała się, bo nie wiedziała - nie przekonała innych edytorów, którzy w tym miejscu zachowali wersję pierwodruku. Jeśli ktoś czyta edycje Pigonia lub Nowaka, dowie się, że Zosia nie wiedziała. Podstawowy problem polega jednak na tym, że odwoływanie się do własnych refleksji badacza zbyt głęboko wkracza w strukturę opracowywanego tekstu.

W zasadzie bez końca można by podejmować dyskusję z kolejnymi zmianami wprowadzanymi na podstawie autografów i kwestionować przywracanie wersów, które nie weszły do tekstu drukowanego. Innym, również nie w pełni przekonującym, źródłem emendacji są egzemplarze wydania z 1844 roku, w których Mickiewicz zapisywał nowe wersje poszczególnych słów. Znane były trzy takie egzemplarze - dwa z własnoręcznymi dopiskami poety (jeden, należący do Eustachego Januszkiewicza, został zniszczony w czasie wojny) i jeden z dopiskami Aleksandra Chodźki, wprowadzanymi pod dyktando Mickiewicza. Część z tych poprawek edytorzy uznali za ostateczną, a więc obowiązującą późniejszych wydawców intencję autora. Nie brali pod uwage jego prawa do zmiany intencji, zwłaszcza tego, że poprawki odzwierciedlają pomysły, które pojawiły się kilkanaście lat po ukończeniu poematu. Przywołam tylko trzy przykłady spośród kilkunastu, które w ten sposób weszły do współczesnych wydań, z wyjątkiem edycji opracowywanych przez Stanisława Pigonia.

Opisując koncert Wojskiego, Mickiewicz w 1834 roku koncentrował się na osobie grającego, toteż wiersz 666 księgi IV w pierwodruku i w wydaniach Pigonia brzmi: „I zagrał: róg jak wicher, nie wstrzymanym dechem, / Niesie w puszczę muzykę". Po latach poeta próbował uchwycić to, co z dźwiękiem dzieje się w instrumencie, na którym gra Wojski. W egzemplarzach Teofila Lenartowicza i Eustachego Januszkiewicza skreślił więc „niewstrzymanym” i na marginesie dopisał „wirowatym”2 Zarówno Górski,

\footnotetext{
2 Podobizna karty z dopiskiem autora w: Winek 2011: 371.
} 
jak i Nowak uwzględnili tę poprawkę w swoich edycjach (idąc śladem wydawców z roku 1858, 1860 i 1868) i drukują: „róg jak wicher, wirowatym dechem" (interpunkcja w każdym z wydań jest inna). W zaginionym dziś egzemplarzu Januszkiewicza, opisanym przez Pigonia w oddzielnym studium (Pigoń 1928: 41), łagodne ,trzpiotalstwo” (ks. V, w. 63) indyczki, na które sarkał indyk, zostało potraktowane przez Mickiewicza bardziej surowo, poeta zamienił je na ,gderanie” i za tym poszli obaj edytorzy - Górski i Nowak. W ten sposób z opisu indyczki zniknął element obrazowy - Słownik Lindego zna jeszcze znaczenie słowa ,trzpiotać” jako machać skrzydłami.

$\mathrm{Na}$ egzemplarzach ostatniego wydania Mickiewicz zmieniał też całe wersy. Na przykład w ks. VII, Rada, w pierwodruku tak został scharakteryzowany Bartek zwany Prusakiem: „W podróżach swych dalekich, wiele zwiedził świata; / Gazet pilny czytelnik, polityki świadom, / Mógł więc nie mało światła udzielić obradom" (w. 6-8). Eustachy Januszkiewicz w wydaniu z roku 1860 na podstawie poprawek autora zastąpił ostatni z cytowanych wersów innym: „W niebytność Maćka zwykle przewodził obradom”, co trochę rolę Bartka pomniejszyło. Pigoń wrócił do wersji pierwodruku i nawet nie odnotował tej różnicy w przypisie. Poprawkę wprowadzili do swoich edycji zarówno Górski, jak i Nowak. Czytelnicy, zwykle nieświadomi różnic, nie spierają się o szczegóły, ale też nie wiedzą, że każdy ma w ręku tekst nieco inny. Odrębnym zagadnieniem są włączane do edycji fragmenty rękopisów, które nie znalazły się w pierwodruku albo w znacznym stopniu różnią się od publikowanej wersji. Zwykle wyjmowano z nich ustępy uznawane za najciekawsze w myśl zasady, że ,powinny być przekazane szerokiemu gronu czytelników” (Winek 2011: 83). Początkowo umieszczano je na końcu w formie wypisów, później jako odmiany tekstu drukowano w aparacie krytycznym albo w przypisach. Poszatkowane w ten sposób rękopisy traciły integralność, a wybierane fragmenty funkcjonowały poza macierzystym kontekstem.

Pośmiertne wydania Pana Tadeusza, które powstały na skutek kompilacji różnych autorskich przekazów i zmian wprowadzanych przez edytorów poprawiających nie dość poprawny tekst autora, nie są najistotniejszym przejawem niestabilności dzieła. Są raczej efektem tej niestabilności i dominującej przez lata, obowiązującej właściwie do dzisiaj, koncepcji edytorstwa naukowego, którą tak w podręczniku wznowionym w 1992 roku definiował Jerzy Starnawski: „Edytor to nie tylko rejent potwierdzający zgodność wydania z autografem czy pierwodrukiem, to także - i to często - detektyw poszukujący. Poszukiwania edytora-detektywa tam zwłaszcza potrzebne, gdzie tekst jest 
wyraźnie uszkodzony, gdzie - wniósłszy np. jedną koniekturę czy emendację - doprowadzimy go do pełnego zrozumienia" (Starnawski 1992: 53). Tu tkwi sedno sprawy - edytor ma czynić dzieło zrozumiałym. Co jednak poza jego intuicją jest miarą czytelności? Właściwa niestabilność tekstu, niedoceniana przez tradycyjne edytorstwo, jest wynikiem działań autora, dla którego proces twórczy bardzo często nie kończy się z oddaniem dzieła do drukarni.

Współczesne myślenie o tekście odwraca tradycyjny porządek. Przede wszystkim odchodzi od kompilacji różnych dokumentów tekstowych. Rezygnuje z konstruowania dzieła, które nigdy w takiej formie nie wyszło spod ręki autora, a w dodatku jego poszczególne elementy należą do różnych porządków. Dowartościowuje wszystkie autorskie przekazy, traktuje je jako dokument pracy nad tekstem, wydobywa ślady pojawiających się i zaniechanych pomysłów, poszukiwanie najlepszych rozwiązań. Coraz częściej interesuje się procesem właśnie. Autorskim dokumentom przypisuje się różny status, cezurę stanowi najczęściej oddanie utworu do drukarni. Poprawki autora na tekście wydrukowanym, jeśli nie ma bezspornych dowodów, że chodzi o niezrealizowane z jakichś powodów wydanie nowe, zmienione, mają mniejszą rangę niż tekst opublikowany, co nie znaczy, że nie trzeba ich brać pod uwagę i interpretować. Dokumentacja Pana Tadeusza jest dość różnorodna. Składają się na nią fragmenty brulionu, znaczna część autografu, dwa wydania autorskie, zniszczony w czasie wojny egzemplarz korektowy, znany z opisu Pigonia, z którego wynika, że jeszcze w korekcie poeta wprowadzał istotne poprawki, na przykład usuwając całe fragmenty.

Wypisy Pigonia z tego egzemplarza są też dobrą ilustracją innego problemu. Na podstawie pojedynczych słów wyrwanych z kontekstu zwykle trudno odtworzyć sens Mickiewiczowskiej redakcji. Pigoń, analizując korektę, tak komentuje postępowanie poety:

Godne uwagi są wypadki, gdzie poeta uszlachetnia stylistyczną tkaninę utworu, słowa, wyrażenia bardziej trywialne czy jaskrawe załagadza i podnosi. (...) W pewnej scenie ks. IX zmienia zarówno szczegóły wypadku, jak i szatę stylistyczną jego wyrażenia. Pierwotnie Płut (IX 299): ,... chwycił Telimeny rękę / I szerokim całusem w białą pierś jej klasnął, / Gdy Tadeusz, przypadłszy z boku, w pysk mu trzasnął.” Korekta poety wniosła tu: „,białe ramię" i „twarz”, i zaraz się zmienił gatunkowy dźwięk odlewu (Pigoń 1928: 29).

- to znaczy uderzenia dłonią na odlew. To kolejny przykład, kiedy Mickiewicz rezygnuje z pierwotnej dosadności. W umieszczanych na końcu współczesnych edycji odmianach tekstu zestawiających „,białe ramię / białą 
pierś” i „twarz / pysk” trudno dostrzec całą pikanterię tej sceny, która sprowokowała bitwę szlachty z Moskalami, a po autorskiej korekcie powód bitwy zyskał znacznie słabsze uzasadnienie.

Do dokumentacji Pana Tadeusza należą poza tym: egzemplarz wydania z roku 1844 z własnoręcznymi dopiskami Mickiewicza, znajdujący się dziś w rękach prywatnych tak zwany egzemplarz Lenartowicza (reprodukcje stron z dopiskami Mickiewicza zamieściła Teresa Winek w swojej książce), inny egzemplarz tego wydania z dopiskami Aleksandra Chodźki nanoszonymi pod kierunkiem poety w roku 1851, wypisy Pigonia ze zniszczonego egzemplarza Januszkiewicza - cztery niewątpliwe poprawki Mickiewicz nanosił zdaniem badacza w 1847 roku, kiedy myślał o przygotowaniu kolejnej edycji swoich dzieł. I jeszcze, należące już do historii tekstu późniejszej niż jego publikacja, króciutkie fragmenty inwokacji wpisywane do albumów (zob. Zgorzelski 1998: [141], [143], 163, 164, 223-224), wreszcie odnaleziona ostatnio karta zawierająca 40 pierwszych wierszy inwokacji z drobnymi, ale ważnymi różnicami w stosunku do tekstu drukowanego, podarowana przez poetę krakowskiemu kolekcjonerowi, Ambrożemu Grabowskiemu (Prussak, Rączka-Jeziorska 2018).

Zadaniem współczesnego edytora powinno być przywrócenie Pana Tadeusza Adamowi Mickiewiczowi oraz takie udostępnienie czytelnikom wszystkich pozostałych dokumentów, żeby nie tylko mieli świadomość, co tak naprawdę czytają, ale też mogli poznać całą złożoną sytuację poematu, który nigdy nie stał się dla jego autora zamkniętą strukturą, choć wybrał jedną jego wersję i ją oddał w ręce czytelników. Żeby - jeśli ich to zainteresuje, mogli poznać proces pracy nad tekstem, a nie arbitralne decyzje edytora rozstrzygającego, który etap tego procesu jest w każdym przypadku wyrazem najwłaściwszej intencji autora. Dokumenty rękopiśmienne miały charakter po części prywatny, albo były osobistymi zapiskami poety, albo przeznaczał je dla konkretnych osób. Dziś powinny być rozpatrywane nie tyle jako ewentualne uzupełnienia przygotowywanej edycji, ile jako zapis niekończącego się namysłu nad własnym tekstem, intensywnej pracy nad formą, dynamiki zmieniającego się dzieła.

Zapis interesujący także wnikliwych czytelników, o czym świadczy choćby opublikowana ostatnio rozmowa Jerzego Illga ze Stanisławem Radwanem. Radwan zachwyca się rytmicznym mistrzostwem poematu i mówi:

Zadałem sobie kiedyś takie pytanie: dlaczego poeta napisał coś w taki sposób, że jest nie do odwrócenia? Trzynaście zgłosek: „Li/two, oj/czy/zno mo/ja, ty 
jes/teś jak zdro/wie”, ale siedem słów: „Litwo, ojczyzno, moja, ty, jesteś, jak, zdrowie”. Cudowny trzynastozgłoskowiec, ale dlaczego poeta ułożył te słowa w takiej kolejności - i to nie tylko ze względu na średniówkę? Przecież mógł napisać: „Ojczyzno moja, Litwo...”, „Moja Litwo, ojczyzno”, „Moja ojczyzno, Litwo...". Powtarzałem to sobie na głos: przecież to nie przemawia, nie porywa, nie idzie do przodu" (Illg 2018: 502).

Znakomity kompozytor nie sprawdził frazy, którą Mickiewicz zaczynał brulion: „Ojczyzno Litwo moja”, ale w czystopisie tę frazę zmienił i zapisał coś, „,co jest nie do odwrócenia”. Może gdyby Radwan czytał równolegle brulion, czystopis i tekst drukowany, poczyniłby jeszcze ciekawsze obserwacje, a na pewno miałby większą przyjemność lektury.

Nie zawsze jednak udaje się ustalić chronologiczny porządek rękopiśmiennych dokumentów. Można gromadzić argumenty i nie znaleźć jednoznacznej odpowiedzi, kiedy Mickiewicz przepisał 40 wersów inwokacji i podarował je Ambrożemu Grabowskiemu. Od publikowanej wersji ta karta różni się w pięciu miejscach, tylko w jednym różnica odtwarza wersję autografu. Najważniejszy jest czwarty wers inwokacji, który poeta zmieniał z dokumentu na dokument i wciąż szukał nowego układu słów, które uchwycą rozpoczynający się właśnie proces tworzenia ${ }^{3}$. W brulionie próbował tak: „Widzę i chcę opiewać, bo tęsknię po tobie”. W czystopisie zmienił: „Widzę, czuję, opiewam, bo tęsknię po tobie”, w pierwodruku jest nowa wersja, ta, którą wszyscy pamiętamy: „Widzę i opisuję, bo tęsknię po tobie". Ale w albumowych wpisach szukał dalej - w zapisie datowanym 17 czerwca 1843, w zagubionym dziś autografie było tak: „Czuję i chcę opisać gdy tęsknię po tobie”. W autografie podarowanym Grabowskiemu jest najprościej, ale dość chropawo: „Czuję i opisuję, bo tęsknię po tobie”. Czucie, jedno z najważniejszych słów w języku Mickiewicza, wracało w kolejnych próbach znalezienia najlepszego wyrazu, bo wciąż okazywało się mocniejsze niż patrzenie. I wciąż zmusza do zastanowienia, czym jest piękno już tylko odczuwane, bo utracone. Skłonna jestem przypuszczać, że ten wpis powstał już po wydrukowaniu poematu, ale mocnych dowodów nie mam. Obserwowanie, jak autor wraca do swojego tekstu i od nowa próbuje formułować go inaczej, tworzy ciekawszą perspektywę lektury, otwiera inne pola skojarzeń. Trzeba jednak pamiętać, że gier poety z własnym dziełem nie da się zamknąć jednoznacznym komentarzem i żadną ostateczną decyzją usuwającą wątpliwości (zob. np. Gabler 1987: 107-16).

3 Początkiem inwokacji zajmował się szczegółowo Kazimierz Wyka. Zob. „Ojczyzno Litwo moja”, w: Wyka 1963: 40-83. 


\section{Bibliografia}

Gabler H.W. 1987. The Text as Process and the Problem of Intentionality, „Text. Transactions of the Society for Textual Scholarship" 3, s. 107-116 .

Górski K. 1969. Wstęp, w: A. Mickiewicz, Dzieła wszystkie, t. IV, Pan Tadeusz, oprac. K. Górski, Wrocław: Ossolineum, s. V-LXVII.

- 2011. Tekstologia i edytorstwo dzieł literackich, Toruń: Wydawnictwo Naukowe UMK. Illg J. 2018. , Zagram ci to kiedyś... ”, Stanisław Radwan w rozmowie z Jerzym Illgiem, Kraków: Znak.

Loth R. 2006. Podstawowe pojęcia i problemy tekstologii i edytorstwa naukowego, Warszawa: IBL PAN.

Méyet L. 1906. Z korespondencji Mickiewicza, „Kurier Warszawski” 326, s. 5.

Mickiewicz, A. 1870. Listy Adama Mickiewicza do A. E. Odyńca. „Kronika Rodzinna” 19.

- 1995. Dzieła, t. IV, Pan Tadeusz, oprac. Z.J. Nowak, Warszawa: SW Czytelnik.

- 2003. Dzieła, t. XV, Listy. Czesść druga 1830-1841, oprac. M. Dernałowicz, E. Jaworska, M. Zielińska, Warszawa: SW Czytelnik.

- 2012, Pan Tadeusz czyli Ostatni zajazd na Litwie. Historia szlachecka z roku 1811 i 1812 we dwunastu księgach wierszem, wydanie dwunaste poprawione, oprac. S. Pigoń, aneks oprac. J. Maślanka, Wrocław: Ossolineum.

Naruszewicz A. 1959. Korespondencja Adama Naruszewicza 1762-1796, z papierów po Ludwiku Bernackim uzupełnił, opracował i wydał Julian Platt, red. T. Mikulski, Wrocław: Ossolineum.

Pigoń S. 1928. Egzemplarz korektowy, w: Ze studiów nad tekstem „Pana Tadeusza”. Trzy notatki, Kraków: Towarzystwo Miłośników Książki.

Piechota M. 2014. Jeszcze o ,psach i chartach” z „Pana Tadeusza” (Stynny w mickiewiczologii lapsus calami i jego domniemane klasycystyczne źródło), w: A. Ziołowicz, R. Dąbrowski (red.), Eklektyzmy, synkretyzmy, uniwersa. Z estetyki dzieła epoki oświecenia i romantyzmu, Kraków: Księgarna Akademicka, s. 201-220.

Prussak M., Rączka-Jeziorska T. 2018. Nieznany autograf Adama Mickiewicza. Dwie strony inwokacji ,Pana Tadeusza”, Warszawa: IBL PAN.

Starnawski J. 1992. Praca wydawcy naukowego, Wrocław: Ossolineum.

Stefanowska Z. 2001. Mickiewicz - tradycja i nowatorstwo, w: Z. Stefanowska, Próba zdrowego rozumu. Studia o Mickiewiczu, wyd. II zmienione, Warszawa: Oficyna Wydawnicza Rytm, s. 335-350.

Winek T. 2011. „Pan Tadeusz” Adama Mickiewicza. Autografy i edycje, Toruń-Warszawa: Wydawnictwo IBL PAN.

Wyka K. 1963. Pan Tadeusz. Studia o tekście, Warszawa: PIW.

Zgorzelski C. (oprac.). 1998. Wiersze Adama Mickiewicza w podobiznach autografów. Część druga 1830-1855, oprac. C. Zgorzelski, red. naukowa Z. Stefanowska, M. Kalinowska, Wrocław: Ossolineum. 